\title{
Relationships between protein and energy consumed from milk replacer and starter and calf growth and first-lactation production of Holstein dairy cows
}

\author{
J. Rauba, ${ }^{1,2}$ B. J. Heins, ${ }^{2,3 *}$ H. Chester-Jones, ${ }^{2,4}$ H. L. Diaz, ${ }^{1}$ D. Ziegler, ${ }^{4}$ J. Linn, ${ }^{1}$ and N. Broadwater ${ }^{5}$ \\ ${ }^{1}$ Milk Specialties Global, Eden Prairie, MN 55344 \\ ${ }^{2}$ Department of Animal Science, University of Minnesota Twin Cities, St. Paul 55108 \\ ${ }^{3}$ University of Minnesota West Central Research and Outreach Center, Morris 56267 \\ ${ }^{4}$ University of Minnesota Southern Research and Outreach Center, Waseca 56093 \\ ${ }^{5}$ University of Minnesota Extension Service Emeritus, Rochester 55904
}

\section{ABSTRACT}

The objective was to determine relationships between protein and energy consumed from milk replacer and starter and calf growth and first-lactation production of Holstein heifer calves. Milk replacer and starter protein intake and metabolizable energy (ME) intake data were collected from 4,534 Holstein heifer calves for growth and 3,627 Holstein cows for production from birth year of 2004 through 2014. Calves from 3 commercial dairy farms were assigned to 45 different calf research trials at the University of Minnesota Southern Research and Outreach Center, Waseca, Minnesota, from 3 to 195 $\mathrm{d}$ of life. Calves were moved to heifer growers at 6 mo of age, and calves were returned to their farm of birth a few weeks before calving. Most calves (85\%) were fed a $20 \%$ crude protein and $20 \%$ fat milk replacer at a rate of $0.57 \mathrm{~kg} /$ calf daily. Metabolizable energy and protein consumed from milk replacer and starter were calculated for each individual calf for 6 and 8 wk of age. Mixed model analyses were conducted to determine the effect of protein and energy consumed from both milk replacer and starter on calf growth and firstlactation 305-d production of milk, fat, and protein, adjusting for herd, season of birth, year, average daily gain (ADG), and calf trial. Calves with ADG $>0.80$ $\mathrm{kg} / \mathrm{d}$ consumed more combined protein and ME than calves with lower ADG. Protein and ME intake from calf starter affected growth more than protein and ME intake from milk replacer because most calves were fed the same fixed amount of milk replacer. Calves born during the fall and winter had greater combined protein and ME intake than calves born during the spring and summer. Milk replacer protein and ME intake did

Received May 16, 2018.

Accepted September 8, 2018.

*Corresponding author: hein0106@umn.edu not have a relationship with first-lactation 305-d milk, fat, and protein production. However, starter protein and ME intake during the first 6 and 8 wk of age had a significant positive relationship with first-lactation 305-d milk, fat, and protein production. Consequently, combined protein and combined ME intake had a positive effect on 305-d milk, fat, and protein production. Variance in protein and ME intake was high, suggesting that additional factors affect calf growth during the first 8 wk of life and milk production in first lactation. Key words: milk replacer, starter, metabolizable energy, first-lactation production, early-life growth

\section{INTRODUCTION}

The Dairy NRC (2001) provides nutrient guidelines to maximize calf health and lean tissue growth and protein requirements to maximize growth. Achieving faster growth and ensuring the health of the calf involves numerous factors, including colostrum management, proper hygiene, and feeding management. Many different calf milk replacer (MR) and starter options are available to feed to dairy calves, many of which have undergone research by scientists and nutritionists. With so many options, dairy farmers may find themselves overwhelmed as to which option will truly help them achieve greater calf growth and optimize health.

Understanding the relationship between protein and energy required for a growing calf is valuable to achieve optimal growth. Various studies have evaluated the protein and energy provided in the diet and their relationship with calf growth (Hill et al., 2013; Kertz and Loften, 2013; de Paula et al., 2017). de Paula et al. (2017) found that feeding more total energy had an effect on calf growth to 10 wk of age. A review by Kertz and Loften (2013) found that a MR containing CP above $20 \%$ is beneficial to calves to achieve lean tissue growth. Sejrsen and Purup (1997) found that feeding 
excess fat could lead to developmental detriments, such as mammary development.

Calves that consumed greater amounts of energy and protein had greater gains as well as increased feed efficiency from 2 to 8 and from 8 to 14 wk of life in a study conducted by Brown et al. (2005). Those investigators also found that, to achieve a younger age of puberty, calves must be fed a diet with increased protein and energy while avoiding any issues associated with excess fattening (Sejrsen and Purup, 1997). Calves that were fed a high-protein MR $(30.3 \% \mathrm{CP})$ and lower fat (15.9\%) would provide $4.4 \mathrm{kcal}$ of $\mathrm{ME} / \mathrm{g}$ of DM and diminish the risks associated with excess fattening (Brown et al., 2005). Hill et al. (2009) noted that an intake of $3.71 \mathrm{Mcal} / \mathrm{kg}$ of ME $(0.0743 \mathrm{Mcal} / \mathrm{d}$ of $\mathrm{BW}$ ) and a ratio of $55 \mathrm{~g}$ of $\mathrm{CP} /$ Mcal per day of $\mathrm{ME}$ was optimal in MR including $2.44 \%$ Lys and $0.75 \%$ Met. The NRC (2001) indicated that, for a $40-\mathrm{kg}$ calf gaining $0.6 \mathrm{~kg} / \mathrm{d}, 59.6 \mathrm{~g}$ of $\mathrm{CP} / \mathrm{Mcal}$ of $\mathrm{ME}$ is required when $\mathrm{MR}$ and starter are fed; for a $50-\mathrm{kg}$ calf gaining $0.8 \mathrm{~kg} / \mathrm{d}, 57.6 \mathrm{~g}$ of $\mathrm{CP} / \mathrm{Mcal}$ of ME is required; and for a $55-\mathrm{kg}$ calf gaining $0.8 \mathrm{~kg} / \mathrm{d}, 55.4 \mathrm{~g}$ of $\mathrm{CP} / \mathrm{Mcal}$ of $\mathrm{ME}$ is required.

First-lactation milk production has been shown to be positively correlated with preweaning ADG and weaning weight (Soberon et al., 2012). The MR diets in Soberon et al. (2012) were a $28 \% \mathrm{CP}$ and $20 \%$ fat (4.87 Mcal of ME $/ \mathrm{kg}$ ) and $28 \% \mathrm{CP}$ and $15 \%$ fat $(4.65$ Mcal of ME $/ \mathrm{kg}$ ). Milk replacer was offered at $1.5 \%$ of birth weight from 1 to $7 \mathrm{~d}$ and 2 to $2.5 \%$ of birth weight from 8 to $42 \mathrm{~d}$, intake was then reduced by $50 \%$ until weaning at $49 \mathrm{~d}$. In their study, a commercially available starter grain was $23 \% \mathrm{CP}$ and $1.84 \mathrm{Mcal}$ of ME/ $\mathrm{kg}$ and was offered free choice at $5 \mathrm{~d}$ of age; intake of calf starter grain was not recorded. Soberon et al. (2012) showed that the higher the nutrient intake preweaning, the more nutrient intake the heifer would have postweaning. Those authors also found that for every kilogram increase in preweaning ADG, first-lactation cows produced an additional $850 \mathrm{~kg}$ of milk and 235 $\mathrm{kg}$ of milk for every megacalorie of total ME intake. More recently, studies have analyzed early life calf growth and it relationship to first-lactation production (Gelsinger et al., 2016; Chester-Jones et al., 2017). In a meta-analysis by Gelsinger et al. (2016), preweaning calf nutrition contributed to a positive effect on 305-d milk and component production. Those authors also emphasized that preweaning calf nutrition from both MR and starter can enhance the effects observed when a producer has excellent management, superior colostrum administration, and superior cleanliness. Finally, Gelsinger et al. (2016) reported that growth rate had little effect on first lactation between 0.3 and 0.5 $\mathrm{kg} / \mathrm{d}$ for ADG, but the effects increased as growth rate increased from 0.5 to $0.9 \mathrm{~kg} / \mathrm{d}$ for ADG. Chester-Jones et al. (2017) found that BW and ADG at 6 and $8 \mathrm{wk}$ positively influenced first-lactation production. For every $1 \mathrm{~kg}$ of 6 -wk ADG, 305-d milk production increased by $544 \mathrm{~kg}$ during first lactation (Chester-Jones et al., 2017)

Based on previous research that determined the relationship between ADG and first-lactation production in Holstein cows in Chester-Jones et al. (2017), the hypothesis of the current study was that improvements in $\mathrm{ME}$ and protein intake during the first $8 \mathrm{wk}$ of life would be associated with increased first-lactation production. Therefore, the objective of our study was to determine relationships between protein and energy consumed from MR and starter and growth and firstlactation performance of Holstein dairy heifer calves. Our findings can be useful information to dairy farmers and nutritionists when planning their calf feeding regimen and can assist in outlining objectives a specific dairy farm has for calf growth and ADG.

\section{MATERIALS AND METHODS}

\section{Calf Management and Data Collection}

Data were collected from birth years 2004 to 2014 for 4,534 Holstein heifer calves. Calves came from 3 commercial dairy farms that together represent over 2,000 dairy cows in Minnesota. Between the age of 2 to $5 \mathrm{~d}$, heifer calves were picked up twice weekly and taken to the University of Minnesota Southern Research and Outreach Center (SROC) in Waseca, Minnesota. Blood samples were taken on d 1 via jugular venipuncture and analyzed for total serum protein concentration using a refractometer (Spartan Refractometer, model A 300 CL, Spartan, Tokyo, Japan). Average serum protein across all farms was $5.5 \mathrm{~g} / \mathrm{dL}(\mathrm{n}=4,534)$. Calves were then assigned to 45 different calf nursery studies at SROC over the 11-yr period.

Each study occurred in the SROC Calf Heifer and Research Facility in individual pens $(2.3 \times 1.2 \mathrm{~m})$ inside 2-curtain sidewall, naturally ventilated $(9 \times$ $61 \mathrm{~m}$ ) barns. The barns contained 2 rooms that held approximately 40 calves per room. In the winter, the pens were bedded with straw. In the summer, the pens were bedded with wood shavings. All the animals were cared for according to the University of Minnesota Institutional Animal Care and Usage Committee recommendations (Current Standard Operating Procedures \#1410B54891).

Of the 45 calf studies in the current data set, the majority of calves (85\%) were fed a MR of all milk 
protein that contained $20 \% \mathrm{CP}$ and $20 \%$ fat. Fifteen percent of the calves were fed $20 \% \mathrm{CP}$ and $20 \%$ fat $\mathrm{MR}$, where alternative animal and vegetable proteins partially replaced milk protein. The alternative protein MR contained either soy, wheat, plasma, or a mixture of both wheat and plasma sources at varying percentages of the total MR protein. Ninety percent of these trials used a MR feeding rate of $0.57 \mathrm{~kg} /$ calf daily. Ten percent of the studies did not feed a conventional $20 \% \mathrm{CP}$ and $20 \%$ fat MR or feed at a rate of $0.57 \mathrm{~kg} /$ calf daily; rather, they fed an accelerated feeding rate regimen. These studies included MR containing protein and fat levels of 24 to $28 \% \mathrm{CP}$ and $20 \%$ fat from 0.57 to over $1 \mathrm{~kg}$ of solids/d. These nutrient levels and varying feeding rates were taken into account when evaluating each calf. The majority of calves were weaned at 6 wk. Data collected on calves included daily MR intake, starter intake, growth (BW and hip height), calf health, and feed efficiency. Body weights were taken every $2 \mathrm{wk}$ until d 56. Standard practices, such as dehorning and vaccinations, occurred during this time.

At approximately 2 mo of age, heifers were moved from the nursery and put into group-housing pens (6.4 $\times 2.7 \mathrm{~m}$ ) with 6 to 8 other heifers for $112 \mathrm{~d}$. Heifers were offered the same starter $(2.72$ to $3.2 \mathrm{~kg} / \mathrm{d})$ as they were fed before weaning for $3 \mathrm{~d}$, and then were fed a $16 \% \mathrm{CP}$ (as-fed) grain mix at the rate of 2.27 to 2.73 $\mathrm{kg}$ /heifer daily. Hay and water were offered ad libitum. The long-stem hay was typically alfalfa or alfalfa and grass mixture. Average composition was $90.4 \%$ DM, $18.8 \% \mathrm{CP}, 46.7 \% \mathrm{NDF}, 33 \% \mathrm{ADF}$, and 132 relative feed value. Hay intake typically averaged 0.54 to $1 \mathrm{~kg} / \mathrm{d}$ for the first $28 \mathrm{~d}$, increasing to $3.8 \mathrm{~kg} / \mathrm{d}$ by $112 \mathrm{~d}$. Hayto-grain mix ratio ranged from $<30 \%$ for $\mathrm{d} 1$ to 28 to $>200 \%$ by d 112 . Heifers remained in these group pens until 6 to 7 mo of age, were moved to heifer growers for about 15 to $18 \mathrm{mo}$, and returned to their original dairy farm before calving.

Protein and ME consumed were calculated for each individual calf for 6 and $8 \mathrm{wk}$. These weeks were chosen because weaning took place at 6 wk and the end of the nursery period was at 8 wk. From 6 to 8 wk, only starter was fed to the calves. Protein consumed was calculated from the protein content of the MR and calf starter. The basic 18\% CP texturized calf starter was the same across years. Starter ME average of 3.28 $\mathrm{Mcal} / \mathrm{kg}$ of DM was used (NRC, 2001) because energy was the same for starter across all the studies. We used NRC (2001) equations to calculate ME as

$$
\begin{aligned}
& \mathrm{ME} \text { of MR }(\mathrm{Mcal} / \mathrm{kg})=[0.057 \times \mathrm{CP}(\%)+0.092 \\
& \times \text { fat }(\%)+0.0395 \times \text { lactose }(\%)] \times 0.9312, \quad[1] \text { and }
\end{aligned}
$$

$$
\begin{aligned}
& \mathrm{ME}(\mathrm{Mcal} / \mathrm{d})=0.1 \mathrm{BW}^{0.75} \\
& +\left(0.84 \mathrm{BW}^{0.355} \times \mathrm{BWG}^{1.2}\right),
\end{aligned}
$$

where BWG is BW gain. First-lactation milk, fat, and protein production records for 3,627 cows of the original 4,534 calves ( $80 \%$ had first-lactation records for the current study) were acquired from Dairy Records Management Systems (Raleigh, NC) and merged with body growth and protein and ME intake data from MR and starter. The production data set included an additional 747 cows compared with a previous study with the same calves that analyzed the relationship between BW and ADG and first-lactation milk production (Chester-Jones et al., 2017).

\section{Statistical Analysis}

Mixed model analyses were conducted with PROC MIXED of SAS (SAS Institute, 2017) to determine the effect of actual protein and ME consumed from milk replacer and starter and the relationship with calf growth and first lactation 305-d milk, fat, and protein production. For calf growth, dependent variables were MR, starter, and combined protein intake from 0 to 6 and 0 to $8 \mathrm{wk}$ and MR, starter, and combined ME intake from 0 to 6 and 0 to 8 wk. The independent variables were herd, birth season (spring, summer, fall, winter), year of birth, and ADG class $(<0.23,0.23-0.34,0.34-0.45$, $0.45-0.57,0.57-0.68,0.68-0.80$, and $>0.80 \mathrm{~kg} / \mathrm{d})$ at 6 and 8 wk nested with herd. Calf trial was a random effect. For production, dependent variables were 305d milk, fat, and protein production and independent variables were herd, birth season (spring, summer, fall, winter), year of birth, MR protein, starter protein, and combined protein consumed from 0 to 6 and 0 to $8 \mathrm{wk}$, as well as MR, starter, and combined ME consumed from 0 to 6 and 0 to $8 \mathrm{wk}$. Again, calf trial was a random effect. Results for ADG class and birth season were reported as least squares means, with significance declared at $P<0.05$

\section{RESULTS AND DISCUSSION}

Table 1 has DMI and ADG from MR and starter, as well as ME intake, protein intake, and first-lactation production (mean $\pm \mathrm{SD}$ ) of the 3 individual farms and across all the farms. For all farms, 6-wk MR protein, starter protein, and combined protein intake averages were $4.7 \pm 1.0,3.6 \pm 1.5$, and $8.4 \pm 1.8 \mathrm{~kg}$, respectively. The mean ADG for 6 wk across all farms was $0.54 \pm 0.1 \mathrm{~kg} / \mathrm{d}$. Six-week total MR ME, starter ME, and combined ME intake were 102.1 $\pm 12.4,57.8 \pm$ 
Table 1. Holstein calf milk replacer, starter intake, BW, ADG, and first-lactation production for all 3 Minnesota herds

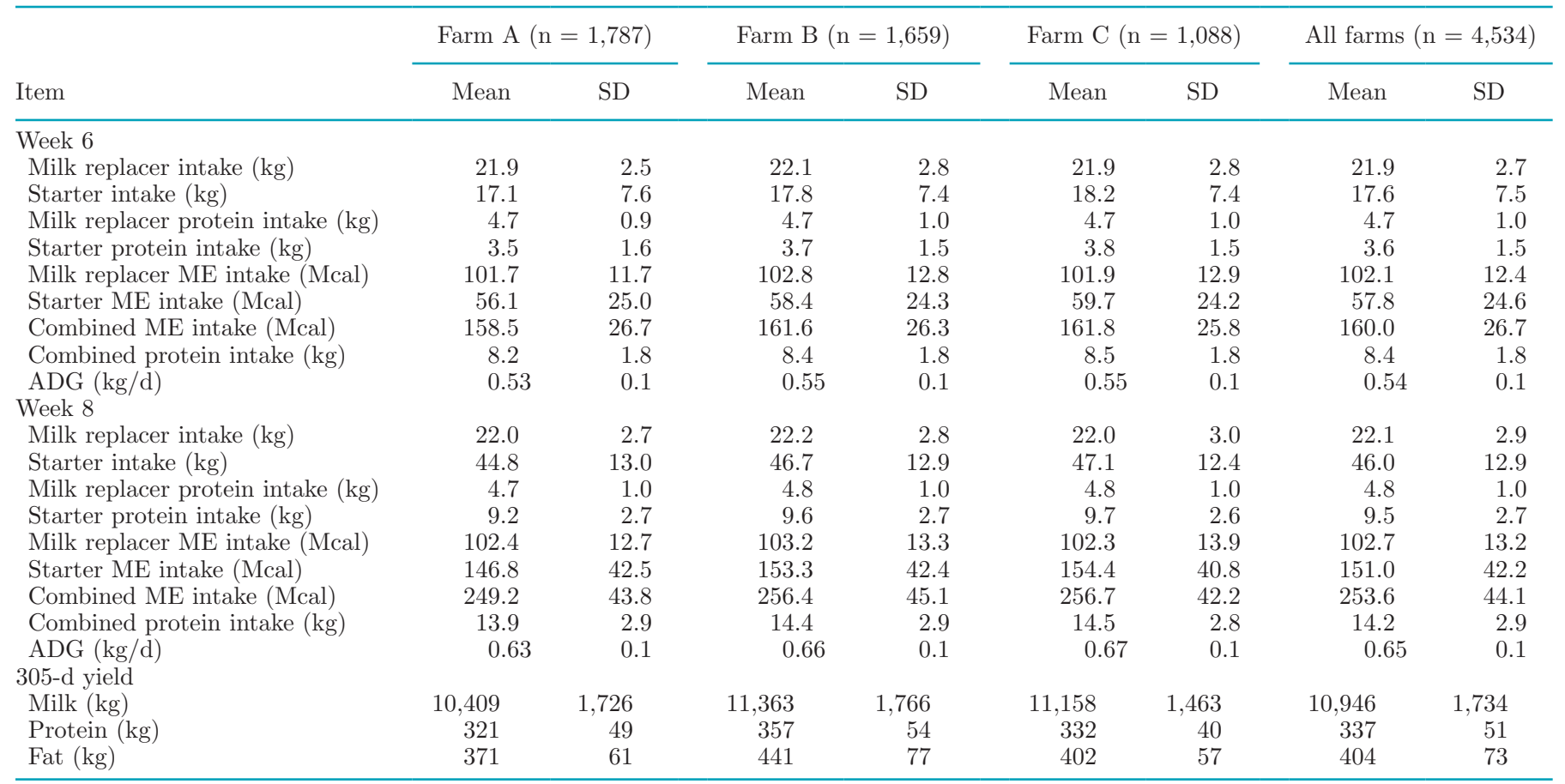

24.6 , and $160.4 \pm 26.4 \mathrm{Mcal}$, respectively. Across all farms, 8-wk MR protein, starter protein, and combined protein averages were $4.8 \pm 1.0,9.5 \pm 2.6$, and $14.2 \pm$ $2.9 \mathrm{~kg}$, respectively, based on $0.7 \mathrm{~kg} / \mathrm{d}$ ADG. Eightweek total MR ME, starter ME, and combined ME intake were $102.7 \pm 13.2,151.0 \pm 42.2$, and $253.6 \pm$ 44.1 Mcal, respectively. First-lactation milk production, protein production, and fat production across all farms were $10,946 \pm 1,734,337 \pm 51$, and $404 \pm 73$ $\mathrm{kg}$, respectively. All calves were managed the same at SROC and, therefore, similarities existed for growth rates from calves from different farms (Table 1).

\section{Early-Life Protein and ME Consumption and Growth}

Least squares means and standard errors of means for ADG classes for 8-wk MR and starter protein and ME consumption are in Table 2. For MR protein consumed, only slight, if any, differences $(P<0.05)$ existed between ADG classes. The majority of the calves in this study did not consume more than $0.57 \mathrm{~kg}$ of MR per day, and, therefore, variation in MR protein consumed was not expected. Most notably, we found no differences $(P>0.05)$ for MR protein consumed for calves that had ADG from 0.23 to $0.34 \mathrm{~kg} / \mathrm{d}$ compared with calves that had ADG greater than $0.80 \mathrm{~kg} / \mathrm{d}$. Calves that had greater ADG in 8 wk consumed more $(P<$ $0.05)$ protein from calf starter compared with calves from the other ADG classes. Consequently, calves that had greater ADG consumed more $(P<0.05)$ combined protein from MR and starter. The CP-to-megacalories of ME ratio for ADG class at $8 \mathrm{wk}$ in the current study were 51.6, 53.6, 54.8, 55.9, 56.7, and $57.6 \mathrm{~g} \mathrm{CP} / \mathrm{Mcal}$ ME for ADG classes 0.23 to $0.34,0.34$ to $0.45,0.45$ to $0.57,0.57$ to $0.68,0.68$ to 0.80 , and $>0.80 \mathrm{~kg} / \mathrm{d}$, respectively. These ratios were similar to those predicted by the NRC (2001) for the higher rates of gain. Stamey et al. (2012) found that preweaning starter DMI was an indicator of greater ADG the week following weaning. The current study complemented Stamey et al. (2012), as both studies showed the significance starter protein consumption had on ADG and growth of preweaning calves. Furthermore, Soberon et al. (2012) reported that ADG for calves fed $28 \% \mathrm{CP}$ and 15 or $20 \%$ fat had greater ADG $(0.82 \mathrm{~kg} / \mathrm{d})$ compared with the calves in the current study that were mainly fed a $20 \% \mathrm{CP}$ and $20 \%$ fat MR.

For MR ME consumption, calves that had an ADG from 0.23 to $0.34 \mathrm{~kg} / \mathrm{d}$ consumed more $(P<0.05)$ $\mathrm{ME}$ than calves in the greater ADG classes. We only had 58 calves in the lowest ADG class, and the small number of calves and the higher standard deviation of those calves may have caused the differences reported between ADG classes. We found no differences $(P>$ 0.05) from MR ME consumed from ADG classes that ranged 0.34 to $0.80 \mathrm{~kg} / \mathrm{d}$. For starter ME consump- 


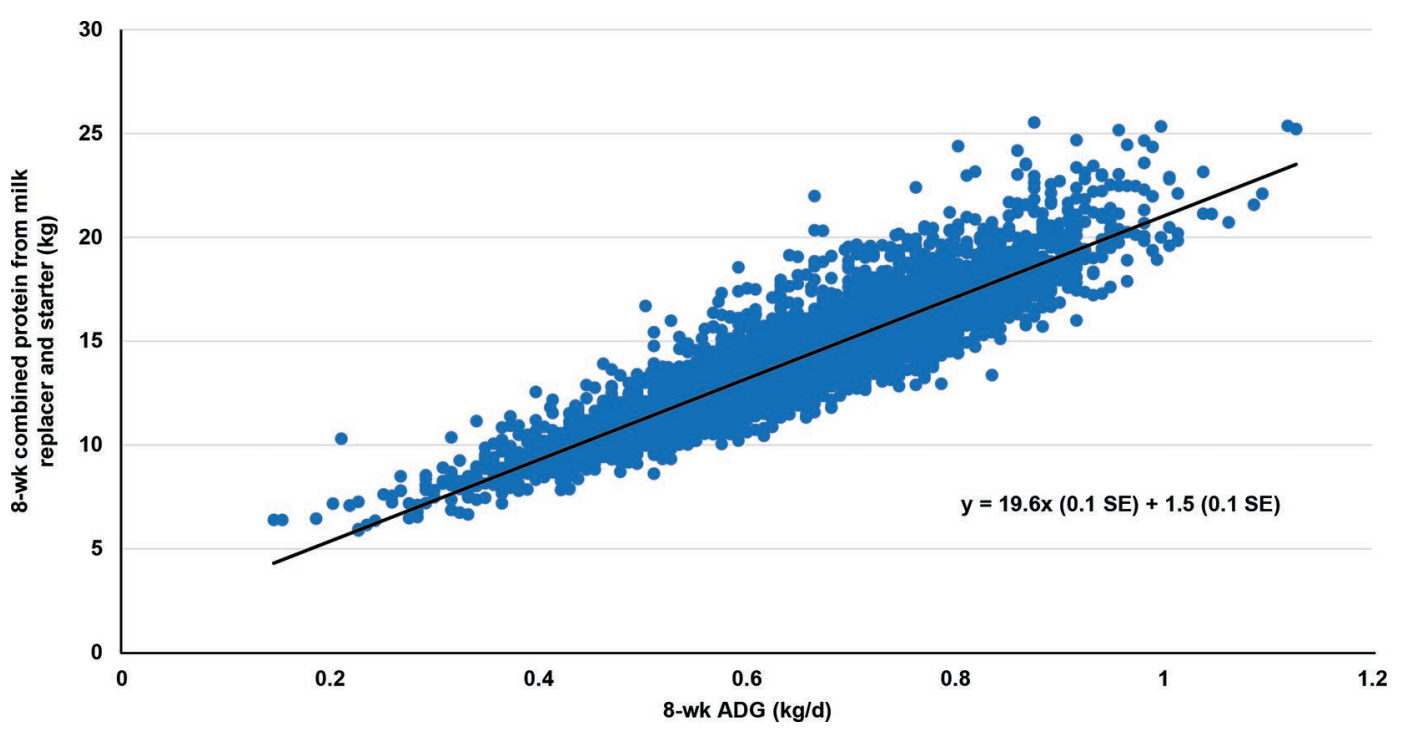

Figure 1. Relationship between 8-wk ADG $(\mathrm{kg} / \mathrm{d})$ and combined protein intake from milk replacer and starter $[\mathrm{y}=19.6 \mathrm{x}(0.1 \mathrm{SE})+1.5$ (0.1 SE)].

tion, calves that had the greatest ADG $(>0.80 \mathrm{~kg} / \mathrm{d})$ consumed the most (206.6 Mcal) starter ME compared with calves that had lower ADG. Similar to combined protein, calves that consumed more combined ME from MR and starter had greater $(P<0.05)$ ADG at $8 \mathrm{wk}$ of age. Figure 1 and Figure 2 illustrate the strong positive relationship that combined protein and combined $\mathrm{ME}$ from MR and starter had with ADG at 8 wk. Generally, a calf that consumes more feed from starter has more protein and ME intake, so the relationship between DMI and nutrient intake is highly correlated.

Whereas high energy from fat has shown to impair mammary development and increase fattening (Sejrsen and Purup, 1997), other studies have found optimal protein-to-ME ratios (Lammers and Heinrichs, 2000; Brown et al., 2005) that optimize growth and lessen the risk of fattening and mammary development impairment. Brown et al. (2005) investigated the effect of increased energy and protein intake and concluded that calves that consumed increased amounts of en- ergy and protein had greater gain and increased feed efficiency through the first 14 wk of life. Dairy farmers may achieve a younger age of puberty and first calving in heifers by manipulating preweaning diets and the amount of energy and protein consumed without the risk of over-conditioned calves and heifers (Lammers and Heinrichs, 2000; Gabler and Heinrichs, 2003; Brown et al., 2005).

\section{Birth Season and Early-Life Protein and ME Consumption and Growth}

The effect of birth season on 8-wk MR and starter protein and ME intake are in Table 3. Calves born during the fall $(13.0 \mathrm{~kg})$ and winter $(13.4 \mathrm{~kg})$ consumed more $(P<0.05)$ combined protein than calves born during the spring $(12.6 \mathrm{~kg})$ and summer $(12.7 \mathrm{~kg})$. The calves born during the winter had the greatest $(P<$ $0.05)$ consumption of protein intake compared with all other calves, which was supported by a higher protein-

Table 2. Average daily gain class at $8 \mathrm{wk}$ for milk replacer and starter protein $(\mathrm{kg})$ and ME $(\mathrm{Mcal})^{1}$

\begin{tabular}{|c|c|c|c|c|c|c|}
\hline \multirow[b]{2}{*}{ Item } & \multicolumn{6}{|c|}{ ADG class } \\
\hline & $0.23-0.34 \mathrm{~kg} / \mathrm{d}$ & $0.34-0.45 \mathrm{~kg} / \mathrm{d}$ & $0.45-0.57 \mathrm{~kg} / \mathrm{d}$ & $0.57-0.68 \mathrm{~kg} / \mathrm{d}$ & $0.68-0.80 \mathrm{~kg} / \mathrm{d}$ & $>0.80 \mathrm{~kg} / \mathrm{d}$ \\
\hline Starter protein & $3.1^{\mathrm{f}}(0.2)$ & $5.2^{\mathrm{e}}(0.1)$ & $7.3^{\mathrm{d}}(0.1)$ & $9.1^{\mathrm{c}}(0.1)$ & $10.8^{\mathrm{b}}(0.1)$ & $13.0^{\mathrm{a}}(0.1)$ \\
\hline Combined protein & $8.2^{\mathrm{f}}(0.2)$ & $10.0^{\mathrm{e}}(0.1)$ & $12.0^{\mathrm{d}}(0.1)$ & $13.8^{\mathrm{c}}(0.1)$ & $15.6^{\mathrm{b}}(0.1)$ & $18.0^{\mathrm{a}}(0.1)$ \\
\hline Milk replacer ME & $108.2^{\mathrm{a}}(2.1)$ & $102.5^{\mathrm{c}}(1.6)$ & $101.6^{\mathrm{c}}(1.5)$ & $101.9^{\mathrm{c}}(1.5)$ & $102.2^{\mathrm{c}}(1.5)$ & $105.1^{\mathrm{b}}(1.5)$ \\
\hline Starter ME & $49.5^{\mathrm{f}}(3.9)$ & $83.5^{\mathrm{e}}(2.1)$ & $117.1^{\mathrm{d}}(1.7)$ & $144.7^{\mathrm{c}}(1.6)$ & $172.6^{\mathrm{b}}(1.6)$ & $206.6^{\mathrm{a}}(1.7)$ \\
\hline
\end{tabular}

\footnotetext{
${ }^{\mathrm{a}-\mathrm{g}}$ Means within the same row with different superscripts are different $(P<0.05)$.
}

${ }^{1}$ Results are least squares means (SE). 
Table 3. Effect of birth season on 8-wk milk replacer and starter protein intake (kg), and milk replacer and starter ME (Mcal)

\begin{tabular}{|c|c|c|c|c|c|}
\hline Variable & $\begin{array}{c}\text { Birth season } \\
P \text {-value }\end{array}$ & Spring & Summer & Fall & Winter \\
\hline Milk replacer protein intake $(\mathrm{kg})$ & 0.03 & $4.9^{\mathrm{ab}}$ & $4.9^{\mathrm{ab}}$ & $4.8^{\mathrm{b}}$ & $4.9^{\mathrm{a}}$ \\
\hline Starter protein intake $(\mathrm{kg})$ & 0.001 & $6.9^{\mathrm{c}}$ & $7.1^{\mathrm{c}}$ & $7.4^{\mathrm{b}}$ & $7.7^{\mathrm{a}}$ \\
\hline Combined protein intake $(\mathrm{kg})$ & 0.001 & $12.6^{\mathrm{c}}$ & $12.7^{\mathrm{c}}$ & $13.0^{\mathrm{b}}$ & $13.4^{\mathrm{a}}-\mathrm{c} \cdot \mathrm{c} \cdot \mathrm{e} \cdot \mathrm{c}$ \\
\hline Milk replacer ME intake (Mcal) & 0.001 & $104.8^{\mathrm{b}}$ & $104.3^{\mathrm{bc}}$ & $103.3^{\mathrm{c}}$ & $106.1^{\mathrm{a}}$ \\
\hline Starter ME intake (Mcal) & 0.001 & $110.4^{\mathrm{c}}$ & $112.3^{\mathrm{c}}$ & $118.6^{\mathrm{b}}$ & $123.3^{\mathrm{a}}$ \\
\hline Combined ME intake (Mcal) & 0.001 & $239.5^{\mathrm{c}}$ & $241.9^{\mathrm{c}}$ & $246.7^{\mathrm{b}}$ & $250.0^{\mathrm{a}}$ \\
\hline
\end{tabular}

${ }^{\mathrm{a}-\mathrm{c}}$ Means within the same row with different superscripts are different $(P<0.05)$.

to-ME ratio The increase in combined protein intake was attributable to increased starter intake during the fall and winter seasons. For ME intake, calves born during the winter had greater $(P<0.05)$ ME intake compared with calves born during the spring, summer, and fall. The combined ME intake follows that of starter protein intake, and calves born during the fall and winter consumed more $(P<0.05) \mathrm{ME}$ than calves born during the spring and summer.

Increased consumption of protein and ME was observed in calves during the fall and winter to maintain or increase growth in cold weather (Kuehn et al., 1994), which was found in the current study. Calves may require more energy for maintenance in harsher environments. The results are similar to Chester-Jones et al. (2017), who reported that calves born during the fall and winter had greater starter intake, BW, and ADG at $8 \mathrm{wk}$ of life. High levels of variation in the growth of calves in these studies that compared birth season suggests that many factors contribute to growth in relationship to a calf's season of birth.

\section{Early-Life Protein Consumption and First-Lactation Performance}

Calf MR protein, starter protein, and combined protein intake at 6 and 8 wk and the effect on firstlactation 305-d milk, fat, and protein production are in Table 4. Milk replacer protein consumption at 6 and 8 wk did not have an effect $(P>0.05)$ on 305-d milk, fat, and protein production during first lactation. Six- and 8-wk starter protein had a positive relationship with first lactation 305-d fat and protein production $(P<$ 0.01 ). Each additional kilogram of calf starter protein intake at $8 \mathrm{wk}$ resulted in 1.31 and $1.32 \mathrm{~kg}$ more $305-\mathrm{d}$ fat and protein production, respectively. Starter protein intake had a tendency $(P<0.06)$ to affect $305-\mathrm{d}$ milk production in first lactation; however, 6 - and 8-wk

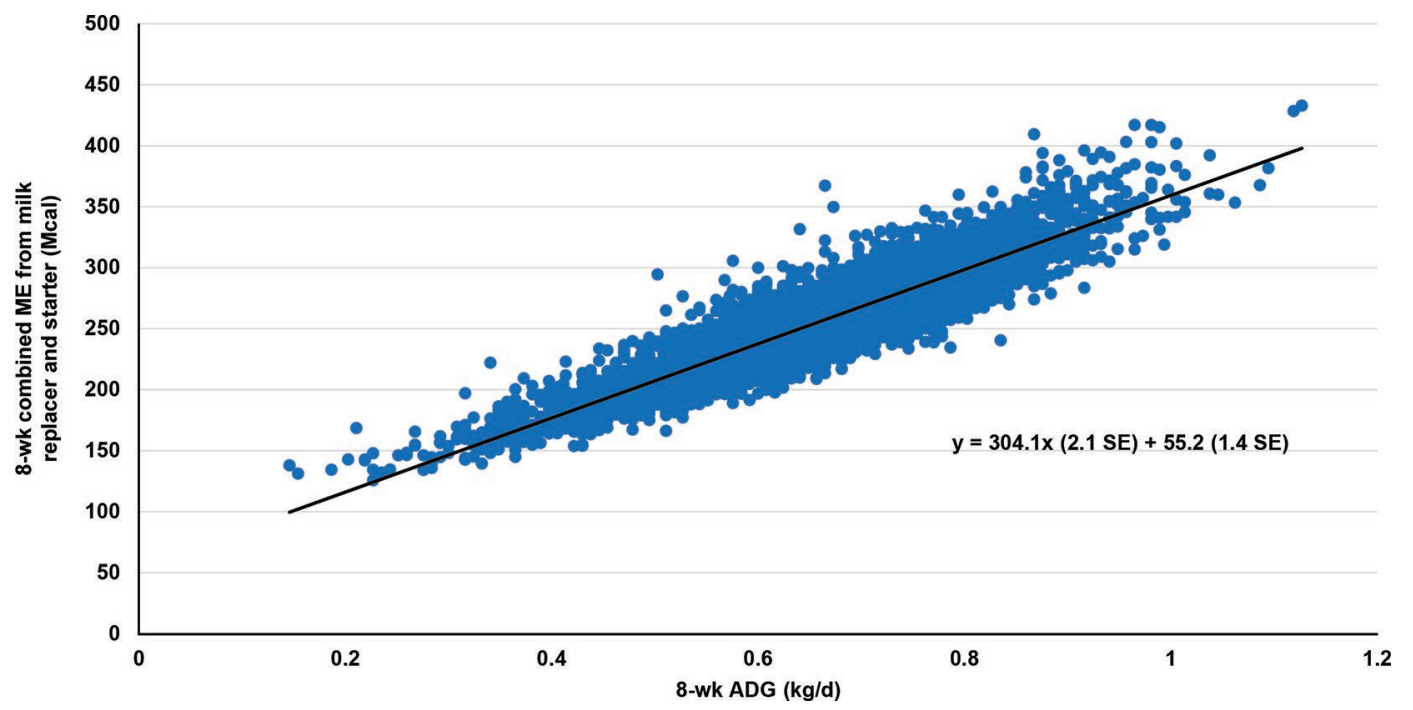
$\mathrm{SE})$.

Figure 2. Relationship between 8-wk ADG $(\mathrm{kg} / \mathrm{d})$ and combined ME intake from milk replacer and starter $[\mathrm{y}=304.1 \mathrm{x}(2.1 \mathrm{SE})+55.2(1.4$ 
Table 4. Regression coefficients for calf milk replacer protein, starter protein, and combined protein intake at 6 and 8 wk for the effect on firstlactation 305-d milk, fat, and protein production $(\mathrm{n}=3,627)$

\begin{tabular}{|c|c|c|c|c|c|c|c|c|c|}
\hline \multirow[b]{2}{*}{ Variable } & \multicolumn{3}{|c|}{ Milk replacer protein $(\mathrm{kg})$} & \multicolumn{3}{|c|}{ Starter protein $(\mathrm{kg})$} & \multicolumn{3}{|c|}{ Combined protein (kg) } \\
\hline & Estimate & $\mathrm{SE}$ & $P$-value & Estimate & $\mathrm{SE}$ & $P$-value & Estimate & $\mathrm{SE}$ & $P$-value \\
\hline 305-d milk & 38.81 & 32.98 & 0.24 & 31.52 & 20.35 & 0.12 & 39.17 & 18.63 & 0.04 \\
\hline 305-d fat & 1.25 & 1.55 & 0.42 & 1.98 & 0.79 & 0.01 & 2.04 & 0.74 & 0.01 \\
\hline 305-d protein & 0.73 & 1.04 & 0.49 & 1.94 & 0.59 & 0.001 & 1.87 & 0.55 & 0.001 \\
\hline \multicolumn{10}{|l|}{ Week 8} \\
\hline 305-d protein & 0.69 & 0.98 & 0.48 & 1.32 & 0.35 & 0.001 & 1.33 & 0.34 & 0.001 \\
\hline
\end{tabular}

combined protein intake had a positive relationship $(P$ $<0.05)$ with 305-d milk, fat, and protein production in first lactation. For every 1-kg increase in combined protein intake at $8 \mathrm{wk}$ of life, milk production increased by $26.04 \mathrm{~kg}$, fat increased by $1.38 \mathrm{~kg}$, and protein increased by $1.33 \mathrm{~kg}$ in $305-\mathrm{d}$ in first lactation (Table 4 ). Perhaps a combination of high protein in MR and calf starter contributed to increase production over $305 \mathrm{~d}$ compared with MR or calf starter protein alone. Differences observed between 6 and 8 wk may be due to management practices after weaning or adjustment for calves after weaning at 6 wk. Gelsinger et al. (2016) reported that management on the farm may have a greater influence on first-lactation production than nutrition and growth before weaning. Although the combined protein intake of calves through the first $8 \mathrm{wk}$ of life had an effect on first lactation production, considerable variation exists in the relationship between combined protein intake at 8 wk of age and 305-d milk production (Figure 3).

Chester-Jones et al. (2017) concluded that calf BW and ADG at 6 and 8 wk had positive effects on 305- d first-lactation milk, fat, and protein production. Similar to the current study, both studies found high variation around the estimates of intake, growth, and first-lactation milk production. Intake of calf starter DM at 8 wk improved first-lactation performance.

\section{Early-Life ME Consumption and First-Lactation Performance}

Calf MR ME, starter ME, and combined ME intake at 6 and 8 wk and their effect on first-lactation 305-d milk, fat, and protein production are in Table 5. The MR ME intake did not have an effect $(P>0.05)$ on 305-d milk, fat, or protein production; however, the starter ME intake had a positive effect $(P<0.05)$ on $305-\mathrm{d}$ fat and protein production.

Six- and 8-wk combined ME intake had a positive relationship $(P<0.05)$ with 305 -d milk, fat, and protein production in first lactation. For every 1-kg increase in combined ME intake at 8 wk of life, milk production increased by $1.80 \mathrm{~kg}$, fat increased by $0.09 \mathrm{~kg}$, and

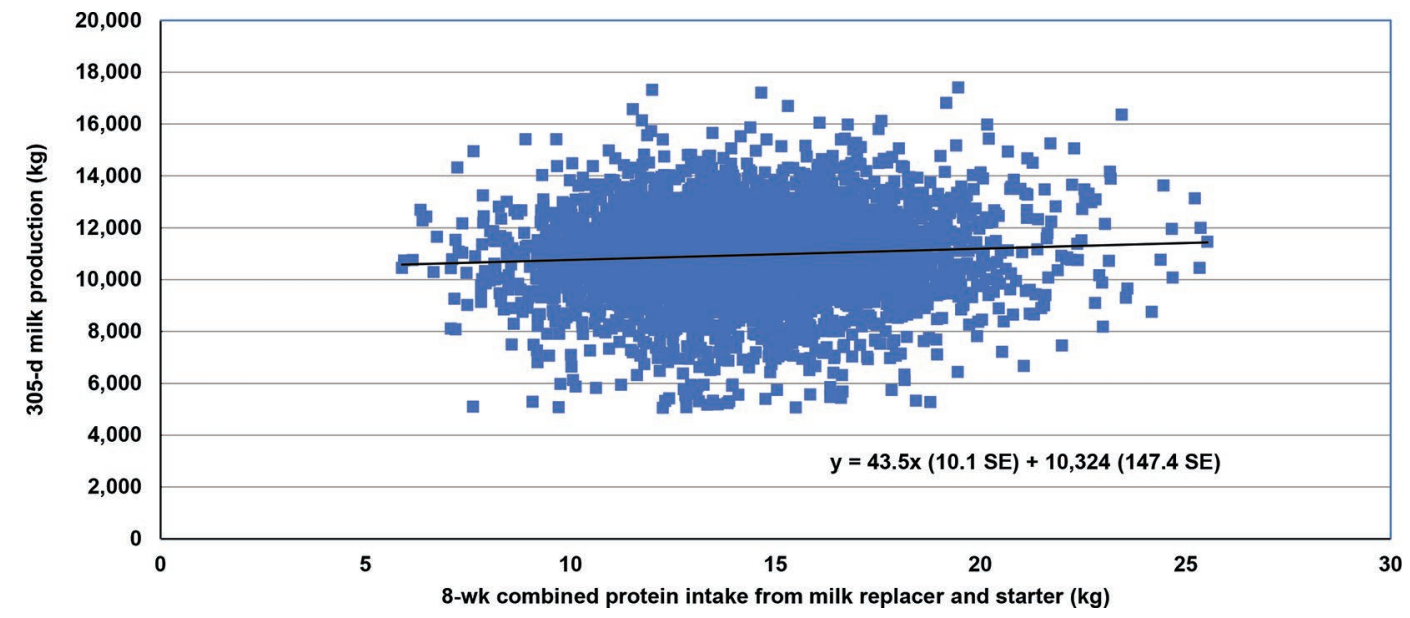

Figure 3. Relationship between 8-wk combined protein intake from milk replacer and starter and first-lactation 305-d milk production (kg) with all calves $(\mathrm{n}=3,627)[\mathrm{y}=43.5 \mathrm{x}(10.1 \mathrm{SE})+10,324(147.4 \mathrm{SE})]$. 
Table 5. Regression coefficients for calf milk replacer ME, starter ME, and combined ME intake (Mcal) at 6 and 8 wk for the effect on firstlactation 305-d milk, fat, and protein production $(\mathrm{n}=3,627)$

\begin{tabular}{|c|c|c|c|c|c|c|c|c|c|}
\hline \multirow[b]{2}{*}{ Variable } & \multicolumn{3}{|c|}{ Milk replacer ME (Mcal) } & \multicolumn{3}{|c|}{ Starter ME (Mcal) } & \multicolumn{3}{|c|}{ Combined ME (Mcal) } \\
\hline & Estimate & $\mathrm{SE}$ & $P$-value & Estimate & $\mathrm{SE}$ & $P$-value & Estimate & $\mathrm{SE}$ & $P$-value \\
\hline \multicolumn{10}{|l|}{ Week 6} \\
\hline 305-d milk & 4.31 & 2.52 & 0.09 & 1.99 & 1.27 & 0.12 & 2.95 & 1.24 & 0.02 \\
\hline 305 -d fat & 0.15 & 0.12 & 0.20 & 0.12 & 0.05 & 0.01 & 0.14 & 0.05 & 0.01 \\
\hline 305-d protein & 0.11 & 0.08 & 0.18 & 0.12 & 0.04 & 0.001 & 0.14 & 0.04 & 0.001 \\
\hline \multicolumn{10}{|l|}{ Week 8} \\
\hline 305-d protein & 0.09 & 0.07 & 0.20 & 0.08 & 0.02 & 0.001 & 0.09 & 0.02 & 0.001 \\
\hline
\end{tabular}

protein increased by $0.09 \mathrm{~kg}$ over $305 \mathrm{~d}$ in the first lactation (Table 5). The current study was contrary to Soberon et al. (2012), who reported a greater increase in milk production in relation to ME intake for calves on an intensified MR-feeding program. This difference reported in the current study is because calves were fed a majority $20 \% \mathrm{CP}$ and $20 \%$ fat at a constant rate while offering starter ad libitum, whereas Soberon et al. (2012) had varying MR composition with higher-protein MR being offered. However, both studies showed that MR and starter play a role in calf growth. Similar to starter protein intake, the relationship of combined ME intake from MR and starter had resulted in a large variation in 305-d milk production (Figure 4).

\section{Birth Season and Early-Life Protein and ME Consumption and First-Lactation Performance}

The effects of birth season on 6- and 8-wk MR and starter protein and ME intake are in Table 6. Calves born during the fall and winter consumed more $(P<$ 0.05) combined protein than calves born during the spring and summer at 6 and 8 wk of age. The calves born during the winter had the greatest $(P<0.05)$ consumption of protein and ME intake compared with all other calves at 6 wk of age. We observed no differences between calves born during the fall and winter for combined protein or ME intake at 8 wk of age. Similar to Chester-Jones et al. (2017), calves born during the winter had lower 305-d milk, fat, and protein production compared with calves born during the summer. Kuehn et al. (1994) stated that increased energy intake by calves is desired to increase growth or the maintenance of growth in cold weather. Our results compliment Soberon et al. (2012), who observed that calves born during the summer produced more first-lactation milk than calves born in the winter.

The ME and protein consumed from MR and starter and its effects on first-lactation production indicate that both MR and starter are important components in the preweaning calf diet. Both combined protein and combined ME are meaningful when it comes to increasing 305-d milk and component production. Birth season plays a role in how much calves consume protein

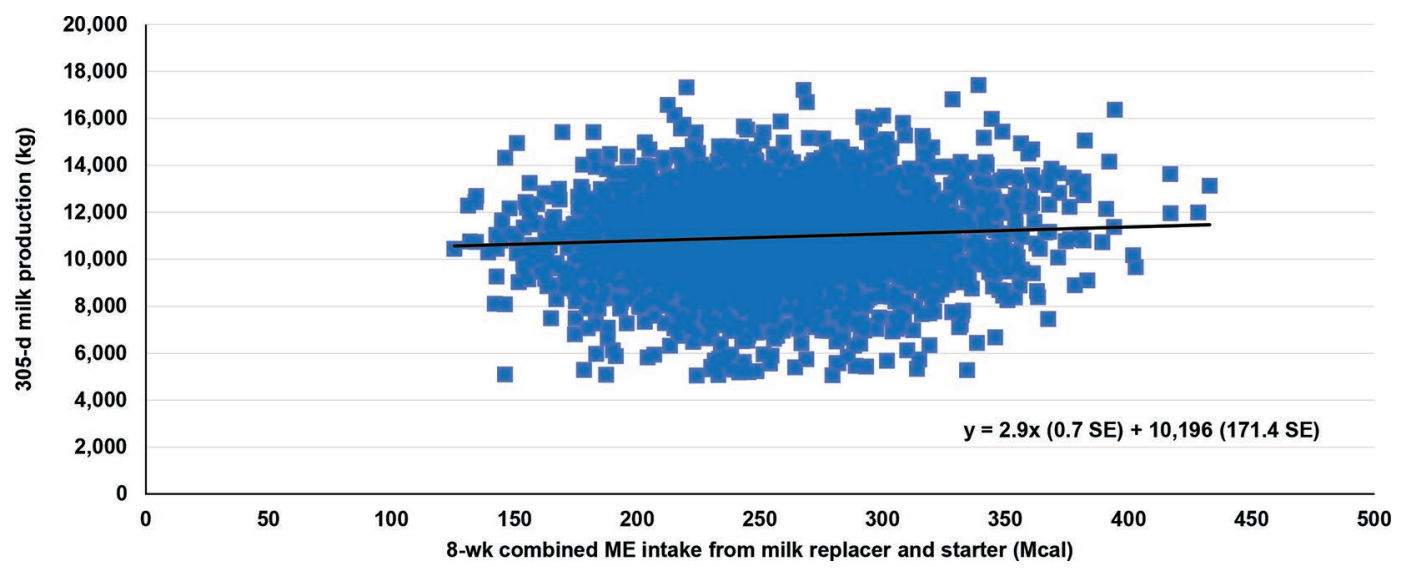

Figure 4. Relationship between 8-wk combined ME intake from milk replacer and starter and first-lactation 305-d milk production (kg) with all calves $(\mathrm{n}=3,627)[\mathrm{y}=2.9 \mathrm{x}(0.7 \mathrm{SE})+10,196(171.4 \mathrm{SE})]$. 
Table 6. Effect of birth season on 6- and 8-wk milk replacer (MR) and starter protein (kg) and ME (Mcal) and first-lactation 305-d milk production $(\mathrm{n}=3,627)$

\begin{tabular}{|c|c|c|c|c|c|}
\hline Variable & $\begin{array}{c}\text { Birth season } \\
P \text {-value }\end{array}$ & Spring & Summer & Fall & Winter \\
\hline \multicolumn{6}{|l|}{ Week 6} \\
\hline MR protein intake $(\mathrm{kg})$ & 0.05 & $4.7^{\mathrm{ab}}$ & $4.7^{\mathrm{ab}}$ & $4.6^{\mathrm{b}}$ & $4.7^{\mathrm{a}}$ \\
\hline Starter protein intake $(\mathrm{kg})$ & 0.001 & $3.4^{\mathrm{b}}$ & $3.4^{\mathrm{b}}$ & $4.0^{\mathrm{a}}$ & $4.2^{\mathrm{a}}$ \\
\hline Combined protein intake $(\mathrm{kg})$ & 0.001 & $8.1^{\mathrm{c}}$ & $8.1^{\mathrm{c}}$ & $8.6^{\mathrm{b}}$ & $8.9^{\mathrm{a}}$ \\
\hline MR ME intake (Mcal) & 0.001 & $101.2^{\mathrm{b}}$ & $101.0^{\mathrm{b}}$ & $99.9^{\mathrm{b}}$ & $102.5^{\mathrm{a}}$ \\
\hline Starter ME intake (Mcal) & 0.001 & $53.7^{\mathrm{b}}$ & $53.7^{\mathrm{b}}$ & $64.2^{\mathrm{a}}$ & $67.0^{\mathrm{a}}$ \\
\hline Combined ME intake (Mcal) & 0.001 & $155.3^{\mathrm{c}}$ & $155.0^{\mathrm{c}}$ & $164.1^{\mathrm{b}}$ & $169.6^{\mathrm{a}}$ \\
\hline \multicolumn{6}{|l|}{ Week 8} \\
\hline MR protein intake $(\mathrm{kg})$ & 0.06 & $4.7^{\mathrm{ab}}$ & $4.7^{\mathrm{a}}$ & $4.6^{\mathrm{b}}$ & $4.7^{\mathrm{a}}$ \\
\hline Starter protein intake $(\mathrm{kg})$ & 0.001 & $9.0^{\mathrm{b}}$ & $9.1^{\mathrm{b}}$ & $10.2^{\mathrm{a}}$ & $10.2^{\mathrm{a}}$ \\
\hline Combined protein intake $(\mathrm{kg})$ & 0.001 & $13.8^{\mathrm{b}}$ & $13.9^{\mathrm{b}}$ & $14.8^{\mathrm{a}}$ & $14.9^{\mathrm{a}}$ \\
\hline MR ME intake (Mcal) & 0.003 & $101.8^{\mathrm{a}}$ & $101.5^{\mathrm{a}}$ & $100.2^{\mathrm{b}}$ & $102.9^{\mathrm{a}}$ \\
\hline Starter ME intake (Mcal) & 0.001 & $143.6^{\mathrm{b}}$ & $144.9^{\mathrm{b}}$ & $162.9^{\mathrm{a}}$ & $162.8^{\mathrm{a}}$ \\
\hline Combined ME intake (Mcal) & 0.001 & $245.9^{\mathrm{b}}$ & $246.8^{\mathrm{b}}$ & $262.9^{\mathrm{a}}$ & $265.8^{\mathrm{a}}$ \\
\hline \multicolumn{6}{|l|}{ Day 305} \\
\hline Milk (kg) & 0.07 & $10,939^{\mathrm{ab}}$ & $11,042^{\mathrm{a}}$ & $10,947^{\mathrm{ab}}$ & $10,831^{\mathrm{b}}$ \\
\hline Fat (kg) & 0.01 & $401.7^{\mathrm{bc}}$ & $408.3^{\mathrm{ab}}$ & $411.2^{\mathrm{a}}$ & $396.3^{\mathrm{c}}$ \\
\hline Protein (kg) & 0.02 & $333.7^{\mathrm{bc}}$ & $338.4^{\mathrm{a}}$ & $338.3^{\mathrm{ab}}$ & $331.6^{\mathrm{c}}$ \\
\hline
\end{tabular}

${ }^{\mathrm{a}-\mathrm{c}}$ Means within the same row with different superscripts are different $(P<0.05)$.

and ME, suggesting that supplementing calf diets with more energy and protein may be beneficial for the calf during colder weather to maintain energy requirements. When planning a feeding program for dairy calves, we suggest that both MR and starter have an effect on the calf through first-lactation production. Further investigation is needed to compare current NRC (2001) requirements to what calves are consuming and how it correlates to ADG and calf growth.

\section{CONCLUSIONS}

Calves fed a $20 \% \mathrm{CP}$ and $20 \%$ fat $\mathrm{MR}$ at a rate of $0.57 \mathrm{~kg} / \mathrm{d}$ had higher intake of both $\mathrm{MR}$ and starter protein during the first 6 wk life and higher intake of both MR and starter ME and higher ADG during the first $8 \mathrm{wk}$ of life, as well as higher ADG. Birth season was a significant factor in the intake of both MR and starter protein and ME, suggesting that calves born in the fall and winter require more energy for daily maintenance than calves born in warmer months. A combination of both early-life MR and starter protein and ME intake positively affected 305-d first-lactation performance. However, variance was high in all the estimates, suggesting additional factors may affect growth to 8 wk of age.

\section{ACKNOWLEDGMENTS}

This paper is a component of USDA Regional Research Project NC-2042; Management Systems to Improve the Economic and Environmental Sustainability of Dairy Enterprises. The authors express gratitude to the technical staff at the Southern Research and Outreach Center (Waseca, MN) for their assistance in data collection and care of animals. In addition, the authors thank Dairy Records Management Systems (Raleigh, NC) for providing lactation data for farms. Financial support was partially provided for this project by Milk Specialties Global (Eden Prairie, MN) and Hubbard Feeds Inc. (Mankato, MN).

\section{REFERENCES}

Brown, E. G., M. J. VandeHaar, K. M. Daniels, J. S. Liesman, L. T. Chapin, D. H. Keisler, and M. S. W. Nielsen. 2005. Effect of increasing energy and protein intake on body growth and carcass composition of heifer calves. J. Dairy Sci. 88:585-594. https://doi .org/10.3168/jds.S0022-0302(05)72722-3.

Chester-Jones, H., B. J. Heins, D. Ziegler, D. Schimek, S. Schuling, B. Ziegler, and N. Broadwater. 2017. Relationships between early-life growth, intake, and birth season with first-lactation performance of Holstein dairy cows. J. Dairy Sci. 100:3697-3704. https://doi .org/10.3168/jds.2016-12229.

de Paula, M. R., C. E. Oltramari, J. T. Silva, M. P. C. Gallo, G. B. Mourão, and C. M. M. Bittar. 2017. Intensive liquid feeding of dairy calves with a medium crude protein milk replacer: Effects on performance, rumen, and blood parameters. J. Dairy Sci. 100:4448-4456. https://doi.org/10.3168/jds.2016-10859.

Gabler, M. T., and A. J. Heinrichs. 2003. Dietary protein to metabolizable energy ratios on feed efficiency and structural growth of prepubertal Holstein heifers. J. Dairy Sci. 86:268-274. https://doi .org/10.3168/jds.S0022-0302(03)73605-4.

Gelsinger, S. L., A. J. Heinrichs, and C. M. Jones. 2016. A metaanalysis of the effects of preweaned calf nutrition and growth on first-lactation performance. J. Dairy Sci. 99:6206-6214. https:// doi.org/10.3168/jds.2015-10744.

Hill, T. M., H. G. Bateman, J. M. Aldrich, and R. L. Schlotterbeck. 2009. Optimizing nutrient ratios in milk replacers for calves less than five weeks of age. J. Dairy Sci. 92:3281-3291. https://doi.org/ $10.3168 /$ jds.2008-1750. 
Hill, T. M., H. G. Bateman II, J. D. Quigley, J. M. Aldrich, R. L. Schlotterbeck, and A. J. Heinrichs. 2013. Review: New information on the protein requirements and diet formulation for dairy calves and heifers since the Dairy NRC 2001. Prof. Anim. Sci. 29:199-207. https://doi.org/10.15232/S1080-7446(15)30225-4.

Kertz, A. F., and J. R. Loften. 2013. Review: A historical perspective of specific milk-replacer feeding programs in the United States and effects on eventual performance of Holstein dairy calves. Prof. Anim. Sci. 29:321-332. https://doi.org/10.15232/S1080 -7446(15)30245-X.

Kuehn, C. S., D. E. Otterby, J. G. Linn, W. G. Olson, H. ChesterJones, G. D. Marx, and J. A. Barmore. 1994. The effect of dietary energy concentration on calf performance. J. Dairy Sci. 77:26212629. https://doi.org/10.3168/jds.S0022-0302(94)77203-9.

Lammers, B. P., and A. J. Heinrichs. 2000. The response of altering the ratio of dietary protein to energy on growth, feed efficiency, and mammary development in rapidly growing prepubertal heif- ers. J. Dairy Sci. 83:977-983. https://doi.org/10.3168/jds.S0022 -0302(00)74962-9.

NRC. 2001. Nutrient Requirements of Dairy Cattle. 7th rev. ed. Natl. Acad. Press, Washington, DC.

SAS Institute. 2017. SAS/STAT Software. Release 9.4. SAS Institute Inc., Cary, NC.

Sejrsen, K., and S. Purup. 1997. Influence of prepubertal feeding level on milk yield potential of dairy heifers: a review. J. Anim. Sci. $75: 828-835$.

Soberon, F., E. Raffrenato, R. W. Everett, and M. E. Van Amburgh. 2012. Preweaning milk replacer intake and effects on long-term productivity of dairy calves. J. Dairy Sci. 95:783-793. https://doi .org/10.3168/jds.2011-4391.

Stamey, J. A., N. A. Janovick, A. F. Kertz, and J. K. Drackley. 2012. Influence of starter protein content on growth of dairy calves in an enhanced early nutrition program. J. Dairy Sci. 95:3327-3336. https://doi.org/10.3168/jds.2011-5107. 